\title{
On the reproduction of the musical economy after the Internet
}

\author{
Andrew Leyshon \\ UnIVERSITY OF NOTTINGHAM, UK \\ Peter Webb \\ University of Birmingham, UK \\ Shaun French \\ UnIVERSITY OF NotTINGHAM, UK \\ Nigel Thrift \\ UNIVERSITY OF OXFORD, UK \\ Louise Crewe \\ University of NotTingham, UK
}

This article examines a crisis of reproduction that began to afflict the music industry in the late 20th century. It considers the causes of the crisis and explores some of the ways in which the industry is being reformed in the face of the emergence of a new regime of socio-technical organization. The musical economy, at the time of writing, was dominated by four large corporations - AOL-Time Warner, Sony/BMG, Universal and EMI - that were responsible for 80 percent of global music sales and had significant interests across the media, entertainment and technology sectors. In the early 21 st century, the music divisions of all these companies experienced a reversal of fortune, linked to falling sales and numerous misplaced investments. This marked a significant break with what, in retrospect, may subsequently be interpreted as a 'golden era' in the history of the music industry, during which it enjoyed about 15 years of steady growth in recorded music sales following the introduction of the compact disc (CDs) as the predominant format for the playback of recorded music (Figure 1). In 2001, global music industry sales fell by 5 percent, and then by over 9

Media, Culture \& Society (C) 2005 SAGE Publications (London, Thousand Oaks and New Delhi), Vol. 27(2): 177-209

[ISSN: 0163-4437 DOI: 10.1177/0163443705050468] 
FIGURE 1

Global music sales, 1970-2001

\$ Billion

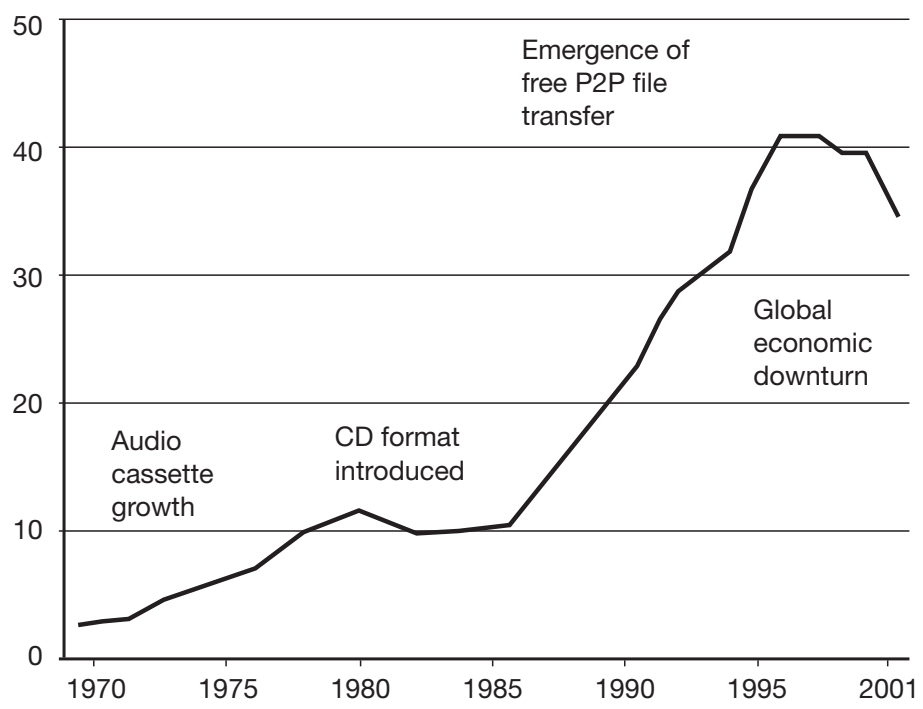

Source: Sanghera, 2001

percent in the first half of 2002 (Sanghera, 2002) (Figure 2). For an industry used to year-on-year sales growth, this reversal had serious consequences, with the leading firms in the sector posting disastrous financial results. Vivendi-Universal, for example, recorded a staggering $\$ 12$ billion loss for the first nine months of 2002 (Economist, 2003a), although part of this loss was due to activities in other areas, such as motion pictures. EMI, which is the least diversified of the major companies, and the most reliant upon sales of recorded music, recorded a financial loss of $£ 54.4$ million in the six months to September 2001 (Economist, 2003b). ${ }^{1}$ The other companies experienced similar losses and, as a result, the major record companies have resorted to dramatic acts and gestures. Rosters of artists and repertoire have been reduced, and have been turned over more rapidly. In extreme cases under-performing acts have been bought out of their contracts altogether, so that the companies can avoid future outlays on production and marketing for material that, in their estimation, would not be recouped. The rapid circulation of artists through record companies has been accompanied by a similar high turnover of staff, within what was already a precarious industry in which to work.

In seeking to account for the poor performance of their businesses in recent years, record company executives are almost as one in identifying 
FIGURE 2

The music industry in crisis

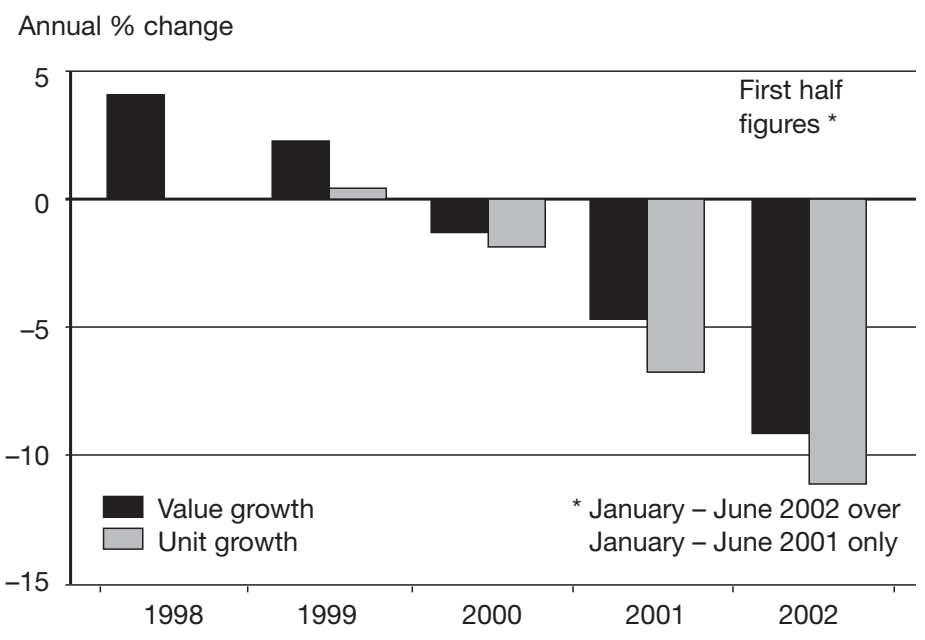

Source: Sanghera, 2002

the main cause of their current malaise: the Internet. Or, more particularly, it is the rise of digital file-sharing systems, such as peer-to-peer (P2P) networks (Leyshon, 2003) that have significantly increased the rate of circulation of illegal copies of copyrighted music, which is identified as the clear and present danger to the survival of the mainstream musical economy (Alderman, 2001; Jones, 2002; Leyshon, 2001; McCourt and Burkart, 2003). It is estimated that in 2002 there were almost 1 billion music files available to be downloaded on the Internet (Sanghera, 2002), and that 27 percent of Americans and 13 percent of Europeans regularly downloaded music through such networks (Economist, 2003c). Representatives of the record industry, such as the Recording Industry Association of America (RIAA) and the International Federation of the Phonographic Industry (IFPI), have been particularly vocal in condemning practices that they claim are contributing to the death of the music industry. The industry points to an inverse correlation between the decline in sales and the rise of software formats such as MP3 to suggest that the former is a result of the latter (see Figure 1). The head of the IFPI recently claimed that the fact that only one CD sold more than 10 million copies world-wide between 2001 and 2002 was a direct result of the Internet (Economist, 2003c). The industry argues that illegal copying and transferring of music over the Internet is increasingly acting as a substitute for sales, which reduces the inflow of capital to the industry that would otherwise be used for the discovery and the development of new acts. In making such claims, the industry has revised and 
updated arguments that first began to circulate from the 1970s onwards, following the growth of music cassette recording technology, when it was argued that 'home taping was killing music'. Moreover, the straightforward way in which cassette recorders could duplicate music encouraged large-scale counterfeiting activities, often linked to organized crime.

There is no question that what the industry describes as 'piracy' has caused the music industry to forego potential earnings in some parts of the world where, for reasons such as a weak civil society or official disregard of acts of copyright infringement for geo-economic reasons (Vaidhyanathan, 2001), the majority of sales of recorded music are in the form of counterfeit cassettes or CDs. For example, the IFPI reports that the global pirate music market totalled 1.9 billion units in 2001, and that as much as 40 percent of all CDs sold world-wide are pirate copies, with the largest markets being China (where 90 percent of the total market is pirated material), Russia (65 percent) and Brazil (55 percent) (IFPI Music Piracy Report, 2002). In such economies, little or no money flows back to the record companies that funded the recording and marketing of the music in the first place, and the pirate music business is often controlled by organized crime syndicates. Some commentators have sought to make a link between what might be described as 'traditional' musical 'piracy', such as the counterfeiting of music in media such as cassettes and CDs, and what has become known as 'Internet piracy'.

However, while some aspects of the Internet economy may be controlled by such elements - with the adult entertainment industry being perhaps the best example (see Zook, 2003) - on-line music can hardly be a sensible area for career criminals to colonize, if only because it makes little if any money. Unlike the adult entertainment industry, consumers have shown a great reluctance to pay for music in digital form, mainly because in recent years so much music has been freely available on the Internet. A quasi-gift economy of music has developed since the mid-1990s, emerging first from IRC (Internet relay chat) networks and evolving into peer-to-peer networks of the kind pioneered by Napster but then developed further by systems such as Gnutella, Morpheus and Kazaa (Beuscart, 2002; Leyshon, 2003). While these activities may be illegal, in that they facilitate the breaching of Euro-American copyright laws, they have failed to develop a convincing business model that would make their operations viable commercial propositions.

Moreover, while such networks are clearly damaging to the profitability of the music industry as it is currently configured, there is evidence to suggest that the rise of Internet piracy cannot be held solely responsible for the depth and severity of the crisis of the musical economy. Rather, we want to argue in this article that the emergence of software formats and Internet distribution systems represent what can be described as a 'tipping point' (Gladwell, 2000) $)^{2}$ that has triggered a wholesale reorganization of 
the music industry towards a new business model. We argue that the problems facing the music industry have not suddenly been manifested overnight, or even in response to on-line digital file exchange, but rather have accumulated over time in response to a set of broader cultural forces that have changed the role of music within society, and relegated its immediacy and importance among many of its consumers. While these problems have been recognized within the industry over many years, it took an anomaly such as the emergence of musical gift economies to begin to bring about recognition of the need for institutional and organizational change.

This article draws upon research undertaken as part of a wider project on e-commerce, and is informed by qualitative interviews with industry informants undertaken within Europe and the United States. ${ }^{3}$ The article is organized as follows. In the next section we explore the relationship between music and value, and develop the argument that the music industry's problems are deeper and more long-standing than the recent furore over MP3 and other software formats would suggest. Nevertheless, the emergence of Internet piracy is one of the most important episodes in the history of the music industry, and it has acted as a catalyst to usher in a period of significant reorganization. In the section 'Reproducing the musical economy', we consider the proliferation of music business models that have emerged within the industry's expanded ecology as it responds to, and seeks to incorporate, on-line distribution models. We argue that these models may be emerging as more appropriate forms of accumulation and reproduction than the per-unit pricing model upon which the music industry was based for most of the 20th century. One or more of these models are likely to be incorporated within a reconfigured music industry that may prove to be better adapted to the cultural and socio-technical changes that have impacted upon the industry in recent years. The next section contains a discussion and summary of the empirical material and is followed by the conclusion.

\section{Valuing music}

One of the classic criticisms of the popular music industry is that it trivializes and debases what is otherwise a potentially radical form of affect. Criticisms of this kind are associated in particular with Theodore Adorno, who argued that popular music 'was bad, bound to be bad, without exception' (1976: 225). His criticism was fuelled by his belief that popular music, produced in line with capitalist means of production, was merely an appeal to the lowest common cultural denominator and distracted its audiences from the realities of their social subjugation. Adorno argued that the value of more 'difficult' classic music was that it demanded that its 
audiences pay it their full attention. Such acts of concentration were rewarded by being made aware of the possibilities of a world of creativity that exists more or less for its own sake, rather than for the purposes of the reproduction of capital. The 'right' kind of music, Adorno insists, has the radical potential of affect, which can influence the conscious and subconscious mind, and bring into being alternative social possibilities. Popular music, on the other hand, uses repetition and predictability to stultify critical faculties, and to support impoverished social and economic institutions.

At the time that Adorno was writing (in the 1940s), there were a number of developments that seemed to support his suspicions about popular music. These included the increasing use of background music in the workplace to improve efficiency and its emergence in places of consumption to induce spending (Lanza, 1995). In addition, there was the steady growth of the popular music industry as an important sector of the economy in its own right (Chappel and Garafalo, 1977; Frith, 1987; Garofalo, 1999; Sanjek, 1988). Arguments supporting Adorno's thesis continue to resurface from time to time, mainly to bolster conservative and elitist critiques of musical culture that are anxious to claim classical musical production and consumption as a superior and more demanding form of expression (for a recent example, see Johnson, 2002). However, under the weight of a sustained critique over the past 30 years, Adorno's arguments have largely been dismissed as those of a well-meaning but mistaken elitist. For one thing, the making of classical music is not undertaken in a vacuum of social relations free of power and inequality. In its earliest forms it was dependent upon aristocratic patronage, while from the 18th century onwards it too was increasingly dependent upon the market, manifested in the growth of the concert hall within large urban centres (see, for example, Attali, 1984). Meanwhile, as a range of studies within cultural studies has shown, popular music is not necessarily passively received but can be given meaning and significance which, in the same way that texts escape their authors, escapes the intentions of its producers and is given agency within a wide range of subcultural movements (see Gelder and Thornton, 1996). Therefore, consumers are not necessarily the dupes of the capitalist record industry as many high cultural critiques of popular music would suggest, but can often subvert these commodities to support lifestyles that cut against the grain of conventional society. ${ }^{4}$

While such subcultural uses of popular music continue, we want to argue that their significance is diminishing as music has increasingly begun to sink into the background of contemporary society and move into an increasingly ambient state. Thus, in a manner that both supports and undermines Adorno's position, we argue that music has become an increasingly important part of the infrastructure of capitalist society, and is 
now an essential crutch to all manner of acts of consumption (DeNora and Belcher, 2000). But, significantly, this development has actually served to weaken the music industry as popular music is decreasingly valued for itself, but is, instead, increasingly valued more for the ways in which it is consumed in relation to other things. This tendency, we argue, is one of the key reasons why the emergence of Internet piracy is such a decisive tipping point for the industry, and is manifested in at least three ways.

The first manifestation may be seen in recent developments within the popular music industry. One of the most important genres of the last decade or so has been dance music and the associated growth of club culture (Malbon, 1999; Thornton, 1995). This genre cuts across normal music industry expectations in a number of ways. Dance music has proved resistant to the industry's attempts to exploit it in accordance with normal practices because the producers of such music are relatively faceless. It is produced through a highly distributed network of recording artists, many of them utilizing relatively cheap computer hardware and software (Hesmondhalgh, 1998). For this reason it is not so much the artists but the DJs that play the music, and the clubs within which the music is played, or the locations in which the clubs are based, that are elevated to the status of stars. The celebrity of both is earned mainly through performance within place, so that while the industry has sought to capitalize upon the reputation of DJs and clubs through branded CDs, the real cultural (and economic) capital attached to the music is earned through actually 'being there'. Thus, the predominant mode of dance music consumption is as a collective experience within a public space (the club). This inverts the normal practice within the music industry where the live music is used as a promotional and marketing tool to support the main source of income, the sale of recorded music. Moreover, equally as important as the sound of the music within the consumption of dance music is the physical and immersive experience of music played at volume within the confined space of the club.

This is linked to the second manifestation, which is the ways in which the consumption of music is increasingly linked to other kinds of media, where the music is valued less for its own qualities than for its association with other phenomena. Thus, the use of music within advertising or within a motion picture or television soundtrack can be the signal for a significant increase in CD sales, often outstripping the sales of artists being promoted through conventional marketing channels. ${ }^{5}$ Ironically, the perceived advantages of cross-selling music on the back of other cultural artefacts - such as motion pictures, for example - was one of the main drivers behind the construction of the large media conglomerates, of which many of the leading record companies are now a part (Negus, 1992; Sadler, 1997). However, the financial benefits of media 'synergy' have proved elusive, partly because 'Amid dizzying talk of convergence, so much attention (and 
cash) has been devoted to securing and developing new forms of distribution that the critical importance of content has often been neglected' (Economist, 2003a). ${ }^{6}$ Moreover, as one of our informants explained to us, although there are many examples of musical 'assets' being used successfully in synergies with other cultural products, there is considerable pressure within media conglomerates to use them in relation to the conglomerate's other internal media assets, as if to justify the existence of the conglomerate, rather than to use them in combination with other cultural products that might be more appropriate but which lie outside the company in question (Interview 1).

The third and final manifestation of the longer-run nature of problems facing the music industry is the way in which popular music no longer commands the attention of consumers in the manner that it perhaps once did. In the immediate post-war period, popular music underwent a significant period of growth as it developed seemingly in lockstep with the identification and naming of the sociological phenomenon of 'the teenager'. Linked to growing levels of affluence and disposable income, it was in the 1950s that people in their teens and early 20 s became the most important market segment within the music industry. The industry would lose significant numbers of consumers as they aged and popular music became less of a central dynamic in their lives, crowded out as it was by the development of other tastes and interests. But, as these older consumers became less interested in popular music, they were simply replaced by new generations of willing music consumers.

However, there is evidence to suggest that, for a number of reasons, the ability of music to command the disposable income of those between the ages of 14 and 24 is ebbing away rapidly. The most simple explanation for this is that other, newer, media and consumer electronics industries have begun to compete for this market segment, so that the amount of money young people have to spend on music has been reduced accordingly. New passions, be it computer games, mobile (cell) phones or even the Internet itself, have all attracted expenditure that, in many cases, was previously spent on music (Economist, 2003c). The comments of the head of BMG UK and Ireland, in an interview with the Financial Times, neatly outlines the dilemma for the music industry by comparing his musical consumption as a youth to that of his own children:

When I was a kid, I'd buy an album and spend hours listening to it and reading the sleeve notes and everything. . . . But my kids get an album and they'll flick through a couple of tracks while they're on their mobile phone and playing on a computer or watching TV. They consume music differently - and when you're spending $£ 20$ a week on a mobile phone, how much money do you have to spend on music? (Hasse Breitholtz, quoted in Sanghera, 2002: 19)

But again, it is important to stress that this phenomenon is not a product of the Internet alone. Indeed, Breen argued in the mid-1990s that the music 
industry has been close to crisis for a long time, at least since the 1980s, and that this crisis has been successfully postponed only by a series of innovations in reproduction technology and the successful opening up of new markets:

... without the introduction of CDs, without classic hits radio, and without new markets in Asia and Latin America, popular music as we know it would no longer exist. The evidence is clear that popular music as a commodity is passing through a rapid transformation, assisted by the introduction of video games from Sega and Nintendo and related new technologies, which has heightened the anxiety circulating among some in the music promotion business. (Breen, 1995: 497-8; see, in addition, Sadler, 1997)

As we have argued above, the growth of Internet piracy may be seen as the tipping point that has converted this anxiety into a fully fledged crisis of reproduction. But it is a tipping point in the sense that it has legitimized participants within the industry to openly talk about a crisis in a way that was more difficult to do previously, if only because it is easier to blame a process that may be located as external to the industry itself. Internet piracy has also unleashed a wide range of new organizational forms as businesses have taken advantage of the opportunities afforded by the impact of the Internet to seek to develop new business models for the music industry.

As has been argued elsewhere (Leyshon, 2001, 2003), the industry is currently experimenting with new organizational and institutional forms to develop new modes of production, distribution and consumption around which the music industry can be re-stabilized, so that it can more effectively reproduce itself after the shock of Internet piracy. One outcome of this period of experimentation has been a more diverse ecology of the musical economy. In the next section of the article, we turn our attention to the proliferation of new organizational forms within the music industry that have developed in response to the impact made by the Internet.

\section{Reproducing the musical economy}

This part of the article draws upon material from research undertaken within the contemporary music industry. It draws upon interviews undertaken with informants within a set of firms that are indicative of key developments currently under way within the industry. Before we examine the position of each of these companies within the emerging ecology of the musical economy, it is important first to give an outline account of the ways in which the music industry has traditionally reproduced itself. Indepth accounts are available elsewhere (see Leyshon, 2001, 2003; Negus, 1992; Sadler, 1997; Scott, 1999), so what follows will be necessarily brief.

The music industry consists of a set of overlapping and interconnecting networks, through which cultural material flows and undergoes a process of 
FIGURE 3

\section{The musical economy as a networked economy}

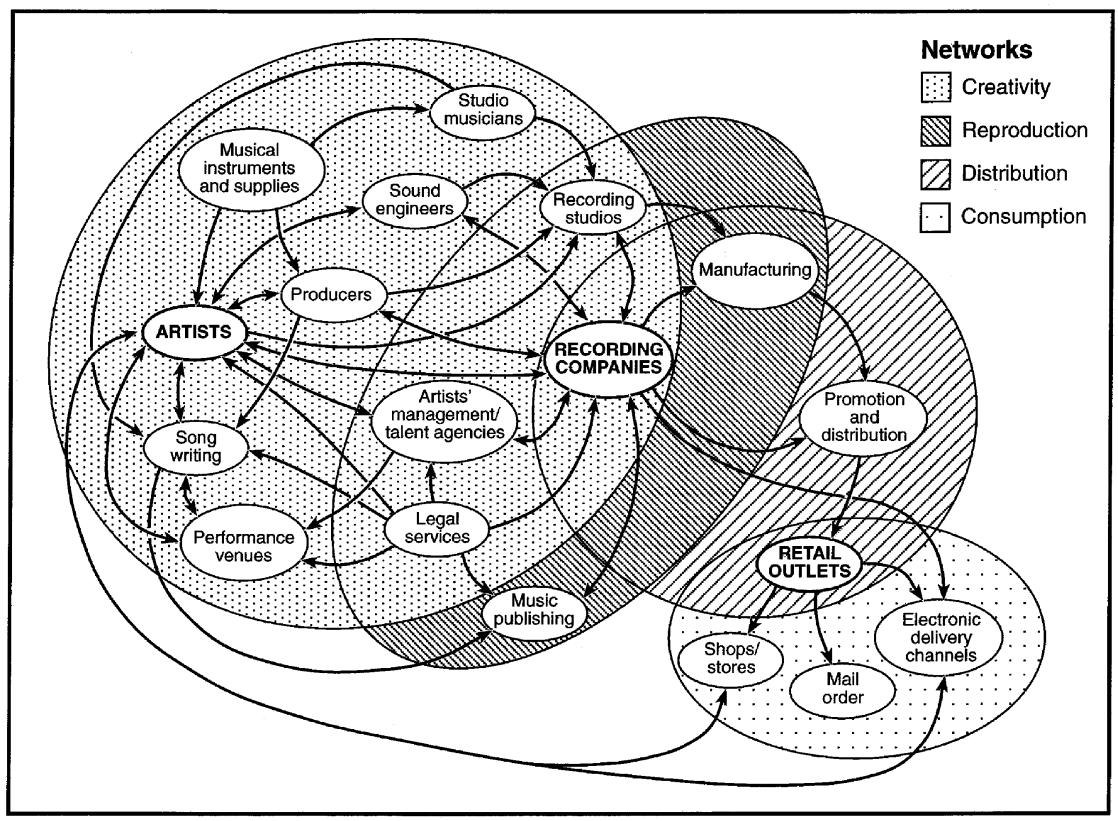

Source: Leyshon (2001)

commodification (Figure 3). Within networks of creativity, music is made and performed, before it is stabilized within networks of reproduction, which has traditionally involved placing the music upon media such as vinyl or $\mathrm{CD}$. In this form, music then enters networks of distribution, wherein the music is moved physically to retail outlets and is promoted and marketed through various media channels (see Leyshon, 2001). Record companies are dominant through these networks, as they act to foster, coordinate and fund talent within networks of creativity, while they actively control the most important assets within networks of reproduction and distribution.

Record companies have reproduced themselves through a combination of per-unit pricing and the enforcement of copyright law. With per-unit pricing, music is viewed as a commodity where each physical unit commands a price that flows back from networks of consumption to the record companies. Copyright law supports this system by enabling those parties claiming ownership of the music and the sound recording - that is, the publishing and recording arms of the record companies - to earn royalties on each unit sold. Strong copyright legislation is important to record companies because it is a notoriously inefficient industry; it is 
estimated that no more than 10 percent of records sold actually recoup the money the record company invests in its production (which includes advances to artists, and the costs of recording, distribution, marketing and advertising). However, while the fixed costs of musical production are high, the marginal costs of its reproduction are low, so that very successful recordings - which can sell in their tens of millions world-wide - can generate large volumes of money. The trade-off between fixed and marginal costs has traditionally enabled the industry to recoup the costs of the 90 percent of recordings that fail to recover the investment made in their production.

That the industry loses money on 90 percent of its business has been explained away by the difficulties of operating within such a volatile and fickle market, which is moved by fashion and taste, and which is very difficult to predict (Scott, 1999). But the precarious imbalance between success and failure also explains why the industry is so concerned about copyright infringements and piracy, because the possibility that piracy might substitute for conventional sales makes it even more difficult for record companies to balance the books so that the industry may be able to reproduce itself. It is for this reason, then, that Internet piracy may be seen as exactly that tipping point; piracy and copyright theft, which was previously seen to be an endemic problem within developing markets, was brought home to its core markets in North America and Europe, exacerbating the other problems facing the music industry discussed earlier. Indeed, evidence from our research within record companies suggest that currently only 3 percent of recordings recoup their investments (Interview 2), and it is upon this very narrow base, in an environment of falling sales, that the rest of the industry is now precariously placed.

In the remainder of this section, the article focuses upon three firms that represent distinctive organizational responses to the current crisis of the music industry. The three firms, the identity of which we have disguised to comply with assurances about confidentiality, are all based or have offices in Southern California. The case studies have been chosen to illustrate some of the strategies and business models currently being tried out in the face of the crisis of reproduction within the industry. The companies include a large traditional, music conglomerate, an on-line subsidiary of a large record company, and an independent artists and repertoire company.

\section{Global Records Inc.}

[The music industry was] never meant to be a big business. If I was in business to be in business I wouldn't be in this business. (Interview 2)

This company is one of the 'big four' media conglomerates that dominates global record sales, with major offices in Los Angeles, New York and 
London. The material in this sub-section is drawn mainly from an interview undertaken in the Los Angeles office with the company's Senior Vice-President for New Media, with responsibility for New Media policies across 40 different labels that make up the record company as a whole.

The company's strategic response to the crisis induced by the advent of software formats and Internet distribution has, like that of other major record companies, combined a set of defensive and offensive manoeuvres intended to attack Internet piracy while, at the same time, seeking to promote the company's strengths and developing internal business models that would enable the company to make money from distributing music in electronic form. Thus, in addition to giving strong support to the RIAA in its aggressive legal actions against companies such as MP3.com and Napster, for example, the company has also been a leading mover in the formation of joint ventures created by the leading record companies to provide music on-line, for a fee. ${ }^{8}$ We will now outline these differing strategies in more detail.

A significant defensive strategy prosecuted by Global Records has been to support and participate in the legal actions brought against P2P filesharing networks. This strategy is time-consuming and expensive, but it has slowly yielded results for the large record companies. Networks such as Napster and Audiogalaxy have been successfully closed down through legal action, and the industry and the RIAA continue to vigorously pursue P2P networks through the courts on the grounds of copyright infringement (McCourt and Burkart, 2003). However, there is now a significant number of competing P2P networks (see Table 1), many with complex organizational and ownership structures, which present new challenges to legal action. For example, take the case of the P2P network Kazaa. A defining feature of P2P networks is that they are a-centred, and difficult to 'ground' once they are in operation. They exist as relational entities, self-organizing software programmes that operate on the Internet through the computers that happen to be running them at any particular time (Leyshon, 2003). However, Kazaa is organized in such a way as to make the task of legal authorities even more difficult, by dividing its operations across a number of different regulatory spaces. ${ }^{9}$ Thus, Kazaa's servers are based in Denmark, the software is programmed in Estonia, the domain name is registered in Australia, with the company that now owns the network, Sharman Networks, registered in the 'no names given' Pacific tax haven of Vanuatu. Therefore, it has been extremely difficult to prosecute and, at the time of writing, has successfully managed to negotiate its way through successive legal attacks launched against it within $\mathrm{US}^{10}$ and European courts. $^{11}$

Given the limits of this form of defensive strategy, ${ }^{12}$ Global Records has also sought to develop more offensive strategies, such as emphasizing the competitive advantages of the traditional roles of a record company, such 
TABLE 1

Peer-to-peer networks, 2003

\begin{tabular}{|c|c|c|c|c|}
\hline Name & Distributor & Business model & Legal status & $\begin{array}{l}\text { Number of } \\
\text { downloads }\end{array}$ \\
\hline Kazaa & $\begin{array}{l}\text { Sharman } \\
\text { Networks }\end{array}$ & $\begin{array}{l}\text { Advertising } \\
\text { supported }\end{array}$ & $\begin{array}{l}\text { Sued by RIAA, } \\
\text { MPAA* }\end{array}$ & 228 million \\
\hline Morpheus & $\begin{array}{l}\text { Streamcast } \\
\text { Networks }\end{array}$ & $\begin{array}{l}\text { Advertising } \\
\text { supported }\end{array}$ & $\begin{array}{l}\text { Sued by RIAA, } \\
\text { MPAA }\end{array}$ & 112 million \\
\hline iMesh & iMesh.com & $\begin{array}{l}\text { Advertising } \\
\text { supported }\end{array}$ & Not sued & 49.7 million \\
\hline Grokster & Grokster & $\begin{array}{l}\text { Commercial } \\
\text { service, supported } \\
\text { by advertising }\end{array}$ & $\begin{array}{l}\text { Sued by RIAA, } \\
\text { MPAA }\end{array}$ & 7.9 million \\
\hline eDonkey & Jed McCalleb & $\begin{array}{l}\text { Advertising } \\
\text { supported }\end{array}$ & Not sued & 50 million \\
\hline BitTorrent & Bram Cohen & $\begin{array}{l}\text { Freely available } \\
\text { technology }\end{array}$ & Not sued & 1.4 million \\
\hline Gnutella & $\begin{array}{l}\text { Various (Open } \\
\text { Source) }\end{array}$ & $\begin{array}{l}\text { Some advertising } \\
\text { supported, others } \\
\text { not }\end{array}$ & Not sued & Unknown \\
\hline
\end{tabular}

* Motion Picture Association of America.

Source: Borland, 2003.

as the promotion, marketing and 'breaking' of artists in a way that the Internet cannot do. Our informant gave the example of a Jamaican band that had played in relative obscurity in the Bahamas for 11 years, during which time they recorded six albums that had sold a combined total of just 4,000 copies. Global Records signed the band, took receipt of a new album and built an intensive marketing campaign around it, which included placing a track from the album within a feature film. The track became a globally successful single and the album sold over one million copies. In contrast to this, the company clearly believes that the marketing potential of the Internet was limited:

There's this model called MP3.com, where anybody could self-publish and put up their own stuff, and what it really was, was geocities for music. The majority of traffic was the band preparing it on site and their friends saying, 'Oh nobody's discovering new music!', because discovering new music happens to be a very difficult and arduous thing. You need to get turned on by somebody whose face is right, [by] your peer group, or [get] your stuff elected into a genre on a radio station, in life, in culture. And that's how you get it. (Interview 2) $)^{13}$

Large record companies justify their role within the musical economy through their role in making popular music both possible and successful. 
Companies insist that music does not just emerge spontaneously, but is produced through the intervention of a set of intermediaries that act upon and channel the music from producers to consumers (see Hennion, 1989). These intermediaries include producers and engineers, artists and repertoire (A\&R) specialists, marketing and media experts, and so on (see Figure 3). The intermediation of such roles and functions represents a significant investment that works to develop talent and make it successful. It is for this reason that there have been, to date, no successful Internet-based challenges to the music industry in the sense that Internet companies have been able to successfully redirect revenue from the established music companies to new intermediaries. ${ }^{14}$ Rather, models such as MP3.com, Napster and P2P networks are seen to be parasitical in that they free ride upon the investments of the music industry but do nothing to actively seek to reproduce the industry through the cultivation of new music.

Nevertheless, a series of extant contradictions and complexities within the music industry have become significantly more problematic in the face of the challenges posed by Internet piracy. A significant problem facing the industry is that musical 'assets' are split between different interests, including the record company, the songwriter, the recording artist and the publisher. The tensions between record companies, who own the rights to the sound recording, and music publishers, who own the rights to the musical work, are often manifested within the same organization - because all entertainment companies contain both kinds of companies - and we shall outline an example of such conflict shortly. In addition, the geography of ownership rights and royalty computations is extraordinarily complex, and is the product of largely national solutions to the problem of generating and collecting income for musicians through mechanical and performance royalties.

These geographically differentiated computations make the attempt by record companies to offensively exploit the Internet, through systems such as PressPlay and MusicNet, significantly more difficult, because of the way it acts against the grain of the traditional price-per-unit industry model:

So what happens is when ... on the Internet, [you say], 'I'm going to download a song of a French band, covering a Beatles tune, owned by Sony Publishing, for myself in Hong Kong, and I'm paying for it with a Japanese credit card.' Okay, is there VAT? Is there sales tax? Under what royalty rates do the song publishers and the bands get [paid]? What country did the transaction take place in? . . . You suddenly realize that for a hundred years our contracts were album based, order based. (Interview 2)

This complex set of ownership rights and regulatory regimes, and the growing tensions between record companies and their publishing arms, means that the industry is often slow to exploit new markets as they 
emerge. Our informant used the example of the growing use of 'ring tones' - tunes that play pieces of music to indicate an incoming call - within mobile telephony. The market for ring tones has increased rapidly over recent years, growing by 58 percent between 2001 and 2002, and generating \$71 million for artists (Economist, 2003d). This market is a potentially significant source of revenue for Global Records, but after setting up the first deal with a small northern European mobile phone company, the company was sued in each territory by the collection societies (on behalf of the music publishers) on the basis that the ring tone was a public performance, and therefore payment should be in the form of a performance royalty. A ruling in favour of the collection societies because ring tones are synthetic versions of songs, rather than the actual sound recordings - meant that neither Global Records, nor any other record company, currently earns any revenue from ring tones (although music publishers and artists do).

A further complication emerges from the fact that most record companies are now part of larger media conglomerates that have divisions that pursue strategies that threaten the reproduction of the musical economy. For example, one of Global Record's media conglomerate competitors had a recorded music division and a technology division that produced computer hardware, including CD 'burners'. To the extent that Internet piracy and illegal CD 'burning' eats into the sales of music within traditional formats, the music division is being undermined from within, so to speak. Another competitor contains a large Internet service provider; it was argued by our informant that it is in the interests of this division to encourage Internet piracy, which might in turn spur more consumers to buy broadband and dial-up access if music remains available on P2P networks. Therefore, once again, the suggestion was that the interests of the ISP division might be seen to be in direct competition with the wing of the company that develops artists and sells music. The major corporations all have increasingly contradictory and divisive tendencies that lead to various elements within the companies pulling in very different directions.

However, the large record companies are also seeking to turn the Internet to their advantage by exploring links with new companies that are trying to exploit a niche in the on-line market. These are subscription-based companies, and include firms such as Listen.com, Fullaudio, OD2, DX3 and Rhapsody. Their business models vary: some permit downloading and burning, while some are merely streaming or jukebox type services. All these companies are reliant upon signing licensing deals with the major companies to ensure that they have content to offer in exchange for their monthly subscription fee. Global Records has signed numerous deals with such subscription companies, and is adopting a wait-and-see strategy to determine which business model proves most effective. 
In the next section of the article, we turn our attention to one such business model, which is pioneering a radically different way of distributing and selling music via an online subscription service.

\section{On-line Music}

The origin of this company, which was based in an out-of-town industrial park in San Diego, was as a dot.com start-up in 1998. It was subsequently purchased by one of the 'big four' companies in 2001, following which it operated as a wholly owned yet autonomous subsidiary within a division that included a set of other recent 'new economy' purchases. ${ }^{15}$ It provided a subscription-based, on-line server for downloading music in MP3 format.

Like many other new on-line music company start-ups that sought to provide a 'legitimate' service, On-line Music was soon forced to confront the dilemma of persuading consumers to pay for music when so much was already available for free on $\mathrm{P} 2 \mathrm{P}$ networks. The company's relative independence from its parent was reflected in its decision to attempt to find a 'work around' to the problem of Internet piracy, rather than attempt to eradicate it through the defensive legal and technological measures prosecuted by big companies such as Global Records:

You don't beat piracy with security; you beat the piracy by providing added value, better service, making it basically easier for people to buy than it is for them to steal, giving them more advantages to buy it. And then of course you do enforcements on people that are breaking the law and illegally distributing it. So that's been our philosophy from day one. (Interview 3)

Repeating an objective expressed by other e-commerce operations, the company indicated that its modus operandi was 'to follow the customer' (Leyshon, 2001), to focus first on what consumers wanted and then to attempt to provide that service. The company originally entered the music business thinking that it could set up an on-line record company. However, like other companies before it, it quickly discovered that this was 'not a good business to be in' (Interview 3). One reason for this is that the people running the putative record company had backgrounds in the software industry, not the music industry, and therefore were not schooled in its complexities.

When still an independent business, the company mutated into an on-line distribution vehicle for a number of independent music labels. The business model that slowly emerged, through trial and error and practical experimentation, was a subscription service that allowed unlimited downloads for a monthly fee of, at the time of writing, just under US $\$ 10$. The system worked as follows. For each track downloaded by the customer, On-line Music made a payment of 7 cents, to be shared between the publishers of 
the music and the record company that held the rights to the sound recording. However, given that the subscription was $\$ 9.99$ per month, a user downloading more than 11 albums per month would guarantee that there would be no revenue left from their subscription for On-line Music to accrue, even before costs. However, the unlimited download model was justified as follows:

We advertise On-line Music as a discovery service. Part of the allure of music on-line is that there are no barriers to entry to try a new artist or a new genre of music. As soon as you place a cap on downloads you are changing the psychology and forcing customers to carefully consider what they download. ... As soon as you tell the customer that they get $\mathrm{x}$ downloads for $\mathrm{x}$ dollars, you are placing a value on each download. As a result the customer will feel that they are not getting their money's worth if they do not download their allotment every month. (Interview 4)

This business model is based upon the tried and trusted system of crosssubsidization. In this case, the company anticipated that the majority of subscribers would be relatively 'light' users of the service. At the same time, the company sought to control and limit what were seen to be 'abuses' of the system, such as continuous and unbroken acts of downloading over 24 hours or more. The advantages of the subscription model over the price-per-unit model are that it provides a steady cash flow and the possibility of developing ever more detailed customer databases. However, subscription systems tend to be less profitable than price-per-unit, and it involves negotiating highly complex licensing deals with record companies (McCourt and Burkart, 2003).

On-line Music's strategy seems to be to position itself as a niche player, operating within the relatively small market served by independent record labels. On the one hand, given that On-line Music is owned by one of the big four record companies, this strategy might be seen as one which enables a large company to derive income from independent competitors that were formerly outside their control, through a capital-intensive distribution system that independent labels could not hope to replicate. On the other hand, this development can be seen as propagating a more diverse ecology of the musical economy, a trend which could be accelerated even further by artists taking album-by-album deals. Our informant illustrated this through an example of an artist who currently has a distribution deal with On-line Music and who had significant critical and commercial success with a band in the late 1980s and early 1990s but who, for the past decade, has been pursuing a career first as a solo artist and more recently with his own band. His albums normally sell 75,000 copies per release, which is far lower than the numbers that a large record label would require to cover the costs of recording and marketing. However, since embarking on his new career, the artist has taken greater control over his commercial affairs and signs distribution deals with labels on an album-to-album basis. 
Moreover, the fact that he owns a recording studio, and uses an oldfashioned 'live to two-track' recording technique, ${ }^{16}$ means the time taken to record material and, significantly, the costs of doing so, have been significantly reduced. Therefore, sales of fewer than 100,000 copies per release nevertheless generate significant earnings for this individual and his employees. ${ }^{17}$

On-line Music now inhabits a distinctive part of the ecology of the musical economy that represents a viable post-Internet model for the industry and many of its artists. Negus (1992) has described the music industry as being a 'web of major and minor companies', suggesting that the outlook and philosophy of both sets of companies are similar but differentiated by scale. In particular, independent labels were seen as akin to creative research and development divisions for the major labels, discovering and sifting new talent that might be turned into successful acts and sell sufficient quantities of music to make them attractive to large record companies. We suggest that the emergence of companies such as On-line Music perform a similar role to that of off-line independents in the past but, significantly, not in the development of artists but rather in the development of business models. In other words, they represent 'research and development divisions' in the quest to develop on-line strategies.

Clearly, On-line Music represents a significant departure for the traditional music industry model. Yet, it still has an important connection to it, and the fact that it is owned by a major record label illustrates that it represents an adaptation that other companies could utilize to accommodate the emergence of software formats and Internet distribution. However, our third and final case study points the way to an even more radical reorganization of the music industry, where the traditional role of the record companies would be significantly reduced, if not removed altogether.

\section{MusicBroker.com}

MusicBroker is an independent A\&R (artists and repertoire) company, which uses the Internet to manage an on-line roster of unsigned acts that it searches for talent in response to demands from major entertainment companies. The company's business model was based upon a perception that the A\&R departments of record companies were overstretched and unable anymore to successfully trawl the clubs, bars and demo tapes for new signings. The company's Chief Operating Officer (COO) and founder described the raison d'etre of the company as follows:

This company's function is to act as a quality filter service for the record industry, to help unsigned bands, artists and songwriters get their music onto the desks of major record companies. (Interview 5) 
The company takes advantage of the high rate of labour turnover in the music industry by employing, on a pro-rata basis, music experts to judge and evaluate music. Their team of evaluators - which includes former vicepresidents of $A \& R$ at major record companies, former programme directors of radio stations, producers, successful songwriters, managers of bands, etc. - give feedback to bands or individual artists who register with the company for a $\$ 300$ annual fee and then pay $\$ 5$ for each song submitted to the company. The feedback takes the form of a report, which is passed back to the artist, which contains a 'MusicBroker rating' plus suggestions on how to improve the work. If the material is good enough, it is sent on to record or film companies that have previously expressed an interest in music of a particular type or genre. The system works as follows:

Record companies tell us what they're looking for as the publishers and music supervisors, we send out information to unsigned artists, bands, songwriters, all over the globe in 30 different countries, via the Internet, via snail mail, if we must, and they respond by sending us music and the response to ... specific requests, kind of like classified ads, we don't disclose that it's Warner Brothers looking for $\mathrm{X}, \mathrm{Y}, \mathrm{Z}$, it'll just say vice-president of $\mathrm{A} \& \mathrm{R}$ of an major label looking for this or that. So the bands can't do an end run around us and inundate the people at the record companies, instead they send the music to us, with a code number on it for that specific request. It goes into a bin with all the other material that's come in for that request. We hire industry experts - who have all been really high-level people who have been involved in the selection and placement of hit music - and we pay them a really good sum of money to come in here and work by the hour to screen every single piece of music for every one of those requests. (Interview 5)

The company is driven by two key assumptions. First, in order to be successful, it has to provide a value-added service to the music industry without undercutting the industry's existing $A \& R$ functions. Thus, the company inverts the logic of traditional A\&R activities by obtaining funding from prospective artists, rather than from retained earnings. The $\$ 300$ annual registration fee, derived from subscriptions from more than 30 different countries ${ }^{18}$ generates sufficient cash flow to enable the company to be able to reproduce itself. Second, that the changing nature of recording equipment (Theberge, 1997) and its increasing affordability means that there are a significant number of musicians making high-quality recordings but who are unsigned:

... the advent of home recording equipment [makes] it plausible if not probable that hundreds of thousands of people on a global scale, maybe millions of people ... now have the ability to make very high-quality demos for next to no money, whereas before they needed to raise $\$ 20, \$ 30, \$ 50,000$ to go to a legitimate studio. They no longer needed to do that. I figured that that influx of recorded talent, [combined with] the small number of A\&R people [meant] that setting up a conduit for those people with a filter on the record company end would be welcomed by both parties. (Interview 5) 
An important area of work is sourcing music for TV and motion picture companies, because it is cheaper for such companies to source new music than pay publishing companies and record companies for the rights to use their music for incidental and background purposes.

MusicBroker begins where the A\&R function of major companies ends, covering the ground conceded by traditional A\&R departments in the wake of a continuing tendency towards capital centralization and concentration, as well as the day-to-day difficulties of looking after existing artists. As a result, "Artists development long dropped off the map of A\&R departments' (Interview 5).

Therefore, the company has managed to carve out an institutional space for itself between the large entertainment companies on the one hand, and a highly distributed mass of unsigned artists and bands on the other, by utilizing the communicative capacity of the Internet. The company is a particularly good example of the externalization of A\&R functions, and one that represents a consolidation of the music industry within dominant cultural centres such as Los Angeles (see Scott, 2000). However, whereas the current activities of the company may be considered to be complementary and beneficial to the industry, the vision that the company has for the future of the musical economy, and of its role within it, has more serious consequences for the large entertainment conglomerates. The role that MusicBroker sees itself playing in the future is as a filter or recommendation service for new music on on-line distribution services that bypass and supplant the traditional networks of the music industry.

This role is predicated upon two predictions about the future of the industry, expressed forcefully during an interview with the company's COO. The first is that, much as we argued earlier in the article, the advent of software formats like MP3 and of Internet distribution systems has made the traditional music industry business model unsustainable, but also that the executives currently running the industry are reluctant to make their organization adapt to a new mode of operation:

Q: So why do you think [the record companies] are having so much trouble [in adapting to MP3 and the Internet]?

A: . . they get paid way too much money, they're definitely afraid of losing their jobs. Based on those things they are afraid to make decisions, they're afraid to take chances, their Boards of Directors demand instant profits, the days of artist development are long gone.... All the record industry needs to do is go back and copy what it did 25 years ago and the problem is solved. But the problem is that it's going to take two or three years of dreadful profits before they're going to start reaping the rewards of that investment in time, energy and straight thinking ... because they know their jobs generally only last for a short amount of time, so why rattle the cage or rock the boat when they're going to be out of the boat in a few years anyway and who gives a shit, they can take their money and their house in Beverley Hills and retire. (Interview 5) 
The second prediction is that the industry will move over to a subscription service but, contra to the earlier example of On-line Music, this will not involve downloading. Rather, the dominant players in the music industry of the (near) future will be Internet Service Providers (ISPs), such as Microsoft Network or AOL, which will control subscription-based interactive music channels:

... people with the most income, who are people who are our age [early 40s], we grew up loving music, we made the music industry as big as it is today, yet we buy very little music now, because we don't have time and we don't like that pimply-faced little kid with the attitude behind the counter at Blockbuster or wherever. However, we still do love music . . . if you could pay, $\$ 10, \$ 20$, $\$ 30$ a month to have a subscription service where you don't download anything, it's all streamed and you've got your 'hard drive in the sky', with your own list, [your own] 'country list', [your own] 'pop list', [your own] 'R\&B list', all the Billboard hot 100 this month for country, R\&B, pop, you know, your list to taste or somebody else's list is modified to taste with your stuff or anybody's list in any form at all, random if you want it. And that is manageable by your computer or by your TV set, and follows you to your cell phone. . . It's your station, [one] that follows you anywhere. You never need to download anything because why do you need to possess something on a hard drive and then transfer [it] to a device, or put it on a disc and take it to you car, if you can get it instantaneously anywhere you are, any time? (Interview 5)

MusicBroker plans to position itself between artists and ISP subscription services by offering an imprimatur of quality. Artists would progress through the MusicBroker filter service and obtain a rating from the company. On the basis of this rating, the artists would be able to sign contracts with ISPs, earning money from what MusicBroker describes as a 'per-chanical' royalty payment; that is, a royalty that is a hybrid of a performance and a mechanical royalty. ${ }^{19}$ The case for such an arrangement is based on combining the scale of ISP networks with a system of micropayments to artists each time the music is played by subscribers to web-based music channels. This is outlined in the following, necessarily extended, interview extract:

. . . let's say that you have a subscription service with 30 million people on a global scale, that's doable - you get 35 million people on AOL - so take that 30 million people on a well-developed, big-time network, globally, and let's say that 10 percent of those people, let's say 20 percent actually, like country music. So that means that you've got, what, 6 million people globally listening to the MSN [Microsoft Network] country station today . . . you're in your car . . . so you determine on your computer, yes, I love these country standards and country oldies, but what about new country? Yes, I'd like to hear new country, and I'd like you to slip it in on this playlist because it's closest to this genre, give it to me every third song. So, you're cruising along in your car and you're hearing a song you've never heard before and you go, 'Oh that sucks!' and [you] hit the delete button, it's gone forever. If you're not sure, you let it play all the way through and if you don't hit the add button by the time it gets to the 
end of the song it's also gone forever. But, if you're liking it, you want to add it to your list on the fly ... you hit the add button, boom! Now [that artist's] song is on your country playlist - that first day it comes out it's going to be heard by 6 million listeners, right. So, let's say you make a penny a piece, that's 6 million people, you made $\$ 60,000$ today on that one play of that song.

... so today you made $\$ 60,000$ on that one song on one network. Okay, let's say only 10 percent of the people who heard it liked it, and added it to their list, well that means that they're going to make $\$ 6000$ tomorrow. But, let's say they only get all the way around the list once every third day, so you're going to make $\$ 6000$ every third day which is like making $\$ 2000$ a day, so you've made $\$ 60,000$ on the first day and then every third day, which you're going to have 100 of those in a year, that's 120 of those a year. 120 times $\$ 6000$, so you're going to make $\$ 720$ grand a year, per penny per listen, on a [inaudible] basis, $\$ 720,000$, so you've just made $\$ 780,000$ on this thing. Realistically let's call it a tenth of a penny you're going to get paid, I have a hard time coming up with a smaller number than that, so you're going to make $\$ 78,000$ on that one song this year. That creates a middle class of musicians, unknown to mankind, now that the home hobbyist can do his thing, on his $\$ 5000$ or $\$ 10,000$ system . . . you've just made yourself at a tenth of a penny per listen you've made yourself $\$ 78,000$ on one song [in a year]. Let's say that you do four of those in a year, you've made $\$ 312$ grand that year, with just four songs. That's a really nice living for four songs and the public doesn't get the 10 shitty songs foisted on them on a $\mathrm{CD}$ anymore. (Interview 5)

Significantly, as indicated above, this opens up the possibility of a middle class of professional musicians who, with the aid of home recording equipment, are able to produce music that will generate significant and regular sums of money. This group of musicians would bridge a gap in the currently highly polarized labour market, where the majority of artists are unsigned and making a meagre income (for example, see Finnegan, 1989), but where a very small minority of artists have become fabulously wealthy.

This vision of the music industry of the future is clearly based upon the business models of other media, such as television and radio. It envisages an arena of musical consumption where intermediaries such as CDs are no longer necessary because wireless devices will be permanently connected to ISP servers, with music available 'on demand' to all those able to pay the subscription fees required to gain access to such services (cf. Rifkin, 2000). Record companies become more or less redundant in this model. Not even their role in discovering, funding and nurturing talent that has ambitions beyond home recording is secure; instead this becomes an opportunity for the venture capital industry, which will treat artists and bands as the equivalent of a business start-up:

To get back to your earlier question, 'What about somebody that makes an expensive recording?'. . . let's say they spend a quarter of a million dollars. Where are they going to get it? [What about] . . . a band who [sic] doesn't have an income yet? They go out and get an investor ... you'll get groups of investors. I know this [happens] from being in the studio end of the business, [you] see anybody from dentists to lawyers to drug dealers investing in new 
artists because it's an ego trip and it's fun. So, if you get an artist that does one home recording, they come to [MusicBroker], they get the stamp of approval, say, 'Look we've already got the stamp of approval, would you like to back us on recording more material? And here's a business plan, here's our business model, we think we can do well, and we need a quarter of a million dollars'. Well, it's not a huge investment, then they can take some of that quarter of a million dollars and they can get themselves . . . an experienced label publicist to promote the fact that the band is going to tour the eastern seaboard, and they get a booking agent to book the shows, you do it all a la carte. . . . That was the premise behind [MusicBroker, that] someday the industry was going to disintegrate and I wanted to be the guy who was going to be the arbiter of good taste because no matter what form it takes, they're only going to be downsizing and somebody is still going to have to be the arbiter of good taste, if I do it for free, nobody can beat that! (Interview 5)

The company's strategy, it emerged, was to just wait until this new musical world moved into view:

... after knowing these people for three years and living in this world since ... 1991, I've come to realize that it's all a bunch of shit, it doesn't mean anything, and that it's just going to take its time and eventually we're going to end up with this subscription streaming service, and all I'm doing is sitting here biding my time but perfecting what we do and refining it and making it better and building our brands, so that when the day comes and somebody needs to step up and be the J.D. Power [of the music industry], ${ }^{20}$ I'm there! (Interview 5)

\section{Discussion}

The case studies outlined in the article illuminate a number of central themes being played out within the contemporary music industry. Thus, Global Records, which represents the strategic response of the major record companies, has deployed a range of offensive and defensive strategies. The company seeks to maintain its dominance within networks of creativity and reproduction, but to change the configuration of networks of distribution by shutting down $\mathrm{P} 2 \mathrm{P}$ networks, replacing them with their own subscription and downloading services while, at the same time, maintaining their position within traditional, physical distribution networks.

In addition, the major companies are moving into areas that they formerly left to press agencies, agents and the artists and their management teams. Thus, the record companies are looking to control new revenue streams now that traditional income sources are being steadily eroded. Efforts are being made to lock artists into deals where the record company can earn a significant share of artist-related merchandising. ${ }^{21}$ It is a process that signifies one of the ways 'in which record companies learn to adapt to a world that loves their artists more than it loves buying their records' (Sandall, 2003: 30). 
The major companies are also stressing the importance of what they see as their critical role in developing a product that is superior to anything that could be developed by artists without music industry intervention. Companies seek to make transparent the role of the producers, engineers, cowriters, artists, marketers and new media departments. Companies such as Global Records emphasize the importance of marketing and promotion and the ability to reach a mass audience that, they insist, is more difficult for on-line companies to achieve. Most of the product that is file-shared and pirated is product that was previously subject to a marketing campaign; indeed, that is why this material is in such demand. These elements, the large companies contend, lend credibility to the idea that the networks of creativity that surround them, and that are in some cases funded by them, are essential to the successful reproduction of the music industry.

Meanwhile, On-line Music is a company that, as an autonomous subsidiary pursuing a subscription model, is located between the majors and the independent companies. The company's business model provides a possible reconciliation of the current crisis of the musical economy wherein subscription services provide content from both major and independent record labels. Its strategy is to navigate between existing networks of reproduction and distribution, but it is a clear herald of a mode of operation that could be adopted by the music industry more generally.

Finally, MusicBroker has, like On-line Music, developed a business model that positions it between labels and artists. Its mission is to obtain deals for artists with record, television or film companies. Thus, MusicBroker is seeking to extract value from networks of creativity by providing services previously unavailable before the advent of the Internet. But, over the longer term, MusicBroker is positioning itself for a more radical restructuring of the networks of the musical economy. Within networks of creativity MusicBroker represents an externalization or re-intermediation of A\&R functions, which shifts the balance of power between artists and record companies and other entertainment companies. This model also assumes that extant networks of reproduction are reconfigured, with a greater focus on home recording. The company envisages networks of distribution being replaced by pure digital distribution through ISPs, subscription services and mobile devices, be they phones or car stereos. The company has positioned itself to take advantage of this proposition, which individuals in and around it are seeking to talk into existence. For example, the CEO of MusicBroker is a member of a Los Angeles-based music industry think-tank that debates ideas surrounding the future of the music industry. This particular knowledge community is developing ideas in the hope that they seep into practice, while at the same time abstracting from the new practices being pioneered by firms like MusicBroker to imagine a new musical economy. 
Whether this particular version of practical virtualism (cf. Leyshon et al., 2005) becomes significant is dependent on a sufficient critical mass of influential individuals and companies within the industry reaching the same conclusion and being able to mobilize the technological and cultural resources to switch the musical economy to a new mode of accumulation and reproduction. Clearly, of the three models discussed, MusicBroker's is both the most radical, but also the most marginal and fragile. A second 'tipping point' - one of reorganization and of new institutional and competitive logics - may be reached with the continued roll-out of broadband, the further financial problems of the major record companies, the continued growth of new companies able to provide new means of accessing music, and the emergence of sufficient music recommendation facilities that would substitute for traditional marketing tools. But this vision of the musical economy remains just that at present, a vision.

\section{Conclusion}

In conclusion, the three companies profiled in this article provide examples of differing strategies in the face of the contemporary crisis of the musical economy. The major companies have sought to adapt to the challenges of software formats and Internet distribution systems through litigation, diversifying through multimedia, seeking to add new revenue streams (such as ring tones and merchandising) while promoting transparency so that people can see the value added by labels in the networks of the musical economy. Meanwhile, new business models, such as those instituted by On-line Music and MusicBroker, seek to reformulate the networks of the musical economy by re-intermediating musical value chains. This includes attempts to radically reconfigure expectations within the industry, for example, by challenging the concept of the 'album', or the notion that an artist needs to be 'discovered' by a record label.

What is clear is that the problems surrounding the decline in sales and the difficulty of enforcing copyright against the backdrop of P2P means that the musical economy is currently an arena within which a range of experiments is being undertaken in an effort to develop new ways of generating income. They range from the highly organized, 'TV spectacular', where programmes such as Pop Stars, Pop/American Idol and Fame Academy showcase new talent to large media audiences, thereby generating large record sales for the record companies that underwrite such events, to the grassroots funding of formerly successful artists who are now unable to secure record deals with major companies, in a process that Michael Lewis (2001) has described as 'interest group economics'.22

In all this, we are reminded of Erica Schoenberger's (1997) analysis of the crisis of US manufacturing in the 1970s and 1980s, whereby once- 
dominant US industrial organizations quickly became uncompetitive in the face of new international rivals. One of the key reasons for the failure of so many companies across a range of industries and sectors was the adoption of inappropriate strategies in the face of crisis. While the leaders of these companies realized that change was necessary, their management of change was compromised by the kinds of investments and interests they had in the organizations that employed them. Schoenberger observes that:

... although there is much talk these days of qualities of leadership and vision, there seems no particular reason to suppose that the problem was a lack of either. Leaders, as we know, can lead right over the edge of the cliff. And it seems far more likely that managers and strategists did have a vision: they envisioned preserving a social order that affirmed the value of their social and material assets and the basis of their social power, and they fought strenuously to make that vision a reality. In the course of that struggle, it seems fair to say, the burden of loss fell disproportionately on people who did not have the power to propose and realize their own vision of the social order. (1997: 227)

Thus, the ways in which these companies responded to new competition were by intensifying and adjusting existing modes of operation, rather than seeking to move over to an entirely different business model.

The parallels with the contemporary musical economy are striking. While it is clear from our interviews with the major record companies that there is a recognition that something must be done that goes beyond the relatively limited defensive and offensive strategies pursued so far, there is a reluctance to embrace the more radical organizational changes that might allow them to accommodate the impact of software formats and Internet distribution systems. A key reason for this, we would conclude, is the stakes that the current leaders of the major record companies have in the preservation of the current social order of the musical economy. And, as in the case of the companies studied by Schoenberger, so the major record companies are resorting to classic strategies of corporate restructuring to tackle problems of declining sales and falling markets. Thus record companies are cutting capacity to match the shrinking rosters of artists, which means that declining sales need to be set off against declining output. At the same time, major record companies are making deep cuts in employment; for example, between 2002 and 2003 EMI shed almost 2000 jobs to generate fixed cost savings of $£ 100$ million, ${ }^{23}$ while Sony Music announced a 10 percent reduction in world-wide employment in $2003 .{ }^{24}$ Finally, record companies are also engaging in 'price gouging', which has seen a 12 percent increase in US CD prices since the onset of the crisis in the late 1990s (McCourt and Burkart, 2003). In the short term, these strategies would appear to be working; for example, between 2002 and 2003 EMI managed to record an 80 percent increase in operating profits. Moreover, as McCourt and Burkart (2003) have argued, the major record companies have successfully used the emergence of Internet piracy as a foil 
to defer anti-trust law suits being prepared against them in the US courts. For these reasons, it should be expected that the traditional music industry business model should survive for some time yet. However, whether the companies that currently dominate the musical economy will be able to do so over the long term without a more fundamental reorganization of their business model remains an open question.

\section{Appendix}

Interviews referred to in this article

\begin{tabular}{|c|c|c|c|c|}
\hline Number & Company & Interviewee & Date & Location \\
\hline 1 & $\begin{array}{l}\text { MediaCon: large } \\
\text { entertainment } \\
\text { corporation with } \\
\text { music division, one } \\
\text { of 'big four' record } \\
\text { companies }\end{array}$ & $\begin{array}{l}\text { Senior Manager, } \\
\text { Network Services }\end{array}$ & $\begin{array}{l}22 \text { October } \\
2002\end{array}$ & Los Angeles \\
\hline 2 & $\begin{array}{l}\text { Global Records: one } \\
\text { of 'big four' record } \\
\text { companies }\end{array}$ & $\begin{array}{l}\text { Senior Vice } \\
\text { President, New } \\
\text { Media }\end{array}$ & $\begin{array}{l}21 \text { October } \\
2002\end{array}$ & Los Angeles \\
\hline 3 & $\begin{array}{l}\text { Online Music: } \\
\text { wholly-owned } \\
\text { subsidiary of World } \\
\text { Music, a large } \\
\text { entertainment } \\
\text { corporation with } \\
\text { music division, one } \\
\text { of 'big four' record } \\
\text { companies }\end{array}$ & $\begin{array}{l}\text { Senior Vice } \\
\text { President }\end{array}$ & $\begin{array}{l}24 \text { October } \\
2002\end{array}$ & San Diego \\
\hline 4 & $\begin{array}{l}\text { Online Music: } \\
\text { wholly-owned } \\
\text { subsidiary of World } \\
\text { Music, a large } \\
\text { entertainment } \\
\text { corporation with } \\
\text { music division, one } \\
\text { of 'big four' record } \\
\text { companies }\end{array}$ & $\begin{array}{l}\text { Senior Vice } \\
\text { President }\end{array}$ & $\begin{array}{l}14 \text { February } \\
2003\end{array}$ & $\begin{array}{l}\text { E-mail } \\
\text { interview }\end{array}$ \\
\hline 5 & $\begin{array}{l}\text { MusicBroker: } \\
\text { independent A\&R } \\
\text { company }\end{array}$ & $\begin{array}{l}\text { Chief Operating } \\
\text { Officer and } \\
\text { founder }\end{array}$ & $\begin{array}{l}31 \text { October } \\
2002\end{array}$ & Los Angeles \\
\hline
\end{tabular}




\section{Notes}

Presentations of this article at the Association of American Geographers conference in New Orleans (March, 2003) and at the Conference on Global Regulation in Brighton (May, 2003) helped to develop some of the ideas contained within it. We are grateful those participants for questions and discussion, and in particular for the comments of Karel Williams and Sol Picciotto. The usual disclaimers apply.

1. Although, for reasons that we outline later in the article, the company has subsequently managed to reverse these losses.

2. While we think the term 'tipping point' is suggestive of the leveraging effects of the cumulative impact of different events, we use it with caution, and wish to distance our analysis from the more impressionistic use of the idea in Gladwell's (2000) book-length treatise on the subject.

3. The broader project has two main aims: first, to account for a role of an e-commerce 'knowledge community' in the formation of a phenomenon such as e-commerce; and, second, to investigate the impact of e-commerce on three industrial sectors, namely the music industry, financial services and the fashion industry. At the time of writing we have undertaken over 60 interviews with industry informants in the United Kingdom, the United States and France. This article draws directly or indirectly on taped and transcribed interviews with music industry representatives based in London, Los Angeles, San Diego and Seattle that were undertaken in 2002. In addition, we draw upon information and views gathered during two User Group meetings with music industry representatives in London in 2002, and a period of participant observation at a leading London record company in 2003.

4. Although this tendency towards subversion has itself been commodified, so that a strand of romanticized 'opposition' has been used over many years to nurture new musical genres within the music industry (see, for example, Negus, 1995).

5. For example, the UK band Dirty Vegas won a 2003 Grammy award for a track used in a TV advertising campaign for Mitsubishi Motors in the US. The track sold more than a million copies in the US, but only 100,000 copies in the UK, where they remain a relatively obscure act (see http://news.bbc.co.uk/1/hi/ entertainment/music/2793511.stm).

6. The way in which synergy was supposed to work has been outlined by Breen (1995: 500):

The [example] comes from Sony and is drawn from the corporation's plans to use Arnold Schwarzenegger in a combination of 'star power and salesmanship'. . . 'Arnie' combined these two roles in Sony Corporation's Last Action Hero, a US\$60 million film. Coming from the Colombia Studios, owned by Sony, the Corporation anticipated that the 'tie-ins' provided across the media would promote Sony products. The film promoted the use of Sony Hardware - by what is known as product placement - so a Sony Walkman mini CD player is used by the film's star. 'Arnie' places a call on a Sony cellular phone. The bands Alice in Chains, AC/DC and rapper Cyprus Hill, all signed on Colombia records and Epic, appear in the film. It is difficult to separate music from the film and technology marketing fetish of the corporation. Music becomes an avenue down which the marketing logic of the corporation moves, constructing contemporary life around the processes of entertainment promotion.

7. Details of the interviews used in this paper are outlined in Appendix 1. Unless otherwise stated, the names of the companies of our informants are 
pseudonyms. The five interviews used in this article are drawn from over 60 undertaken as part of a broader research project on the impact of e-commerce upon the music, financial services and fashion retailing industries.

8. In addition, it should be noted that these services not only require users to pay a subscription, but are also charged per download, with restrictions being placed on the number of times that the music can be copied and, in some instances, how many times it can be played. Thus, in some respects, the service being offered by PressPlay and MusicNet are an uncomfortable mix of a per-unit pricing scheme with a rental service.

9. Thus, P2P networks are pursuing strategies of 'regulatory arbitrage' more commonly associated with the global financial system (see Leyshon and Thrift, 1997).

10. In 2003 the RIAA was pursuing cases against Streamcast Networks, the designers of the Morpheus, Grokster and Kazaa software (http://www.mi2n.com/ press.php3?press_nb $=45017$; and see Table 1). The fact that the cases are aimed at the software designers illustrates the difficulties the RIAA faces in countering P2P networks once they are in action. Moreover, the music industry's pursuit of such entities through the courts has been interspersed with serious legal setbacks, such as a Los Angeles Federal judge's decision in April 2003 that Streamcast and Grokster were not responsible for copyright infringements committed on their networks (Borland, 2003).

11. Kazaa has also been pursued through the Netherlands courts, where the company that initially owned the network was based. It was in response to the court action that the network was sold to the 'nebulous' and elusive Sharman Networks (Tehranian, 2003: 18).

12. Indeed, Tehranian (2003) makes a convincing case that legal action by the music industry against P2P networks has the effect of increasing the number of users of such networks, as the media coverage of such cases brings the existence and possibilities of $\mathrm{P} 2 \mathrm{P}$ to a wider audience.

13. For more on the MP3.com business model, see Leyshon (2003).

14. P2P networks have merely reduced, rather than redirected, revenue flowing to the music companies

15. The timing of this purchase would seem to confirm McCourt and Burkart's (2003: 341) observation that the sharp decline in 'technology stocks' from 2000 onwards, and the consequent drying up of venture capital funds to music-orientated dot.coms that followed the Napster lawsuit in the same year, enabled the five large record companies to acquire Internet distribution systems such as On-line Music for 'below market value, [which] also saved research and development costs', as these companies pioneered new technologies at the expense of venture capitalists and the capital markets (see, also, Feng et al., 2001).

16. That is, the songs are recorded in one take with the voice and instruments being recorded upon just two tracks of tape. The standard modern recording technique is to use multi-tracking techniques, which can include up to 100 separate recording tracks (Cunningham, 1998).

17. A similar argument emerged in our third case study, that of MusicBroker.

18. Although 85 percent of subscribers are based in the United States. In addition to the US, in October 2002 subscribers to the MusicBroker service came from the following countries: Australia, Belarus, Belize, Cameroon, Cayman Islands, Central African Republic, Egypt, Faroe Islands, Great Britain, Ghana, Guatemala, Italy, Lithuania, Luxembourg, Mexico, Netherlands, Somalia, Sri Lanka, Switzerland, Syria, Trinidad, UAE and Ukraine. The list also includes 'East Africa' and the 'West Indies' (MusicBroker, personal communication, 2002). 
19. Performance royalties are paid to music publishers for musical performances, while mechanical royalties are paid to the owners of the sound recording (usually record companies) for the manufacture and sale of individual CDs or albums.

20. J.D. Power \& Associates undertakes consumer satisfaction surveys to provide quality recommendations for consumer products in the USA.

21. For example, in 2002 EMI sign a recording deal with Robbie Williams which guaranteed the record company 25 percent of earnings from the sale of merchandising such as T-shirts, posters, etc. (Sandall, 2003).

22. Lewis gives the example of the band Marillion which has utilized an enthusiastic but distributed fan base to raise cash to pay for tours and albums when traditional sources of funding for such activities within the industry had been denied to them (Lewis, 2001).

23. Taken from EMI Group plc preliminary announcement for year ended 31 March 2003 (source: http://emi.com).

24. Taken from Sony Corporation, Consolidated Financial Results for the Fiscal Year ended 31 March 2003 (source http://sony.com).

\section{References}

Adorno T. (1976) Introduction to the Sociology of Music. New York: Seabury Press.

Alderman, J. (2001) Sonic Boom: Napster, P2P and the Battle for the Future of Music. London: HarperCollins.

Attali, J. (1984) Noise: The Political Economy of Music. Minneapolis: University of Minnesota Press.

Beuscart, J.S. (2002) 'Putting Napster to Use: Between a Community and a Body of Customers - The Construction and Regulation of a Sociotechnical Group', Sociologie Du Travail 44(4): 461-80.

Borland, J. (2003) 'Judge: File-swapping Tools are Legal', CNET News.com 10 June. Available on-line: http://news.com.com/2100-1027-998363.html. Accessed 10 June 2003.

Breen, M. (1995) 'The End of the World as We Know It: Popular Music's Cultural Mobility', Cultural Studies 9(3): 486-504.

Chappel, S. and R. Garafalo (1977) Rock ' $n$ ' Roll is Here to Pay: The History and Politics of the Music Industry. Chicago: Nelson-Hall.

Cunningham, M. (1998) Good Vibrations: A History of Record Production. London: Sanctuary.

DeNora, T. and S. Belcher (2000) “"When You're Trying Something on You Picture Yourself in a Place Where They Are Playing This Kind of Music" Musically Sponsored Agency in the British Clothing Retail Sector', Sociological Review 48(1): 80-101.

Economist (2003a) 'Lights! Camera! No profits!', 16 January. Available on-line: www.economist.com. Accessed 10 June 2003.

Economist (2003b) 'How to Manage a Dream Factory', 16 January. Available online: www.economist.com. Accessed 10 June 2003.

Economist (2003c) 'Unexpected Harmony', 23 January. Available on-line: www. economist.com. Accessed 10 June 2003.

Economist (2003d) 'In a Spin', 27 February. Available on-line: www.economist. com. Accessed 10 June 2003. 
Feng, H.Y., J. Froud, S. Johal, C. Haslam and K. Williams (2001) 'A New Business Model? The Capital Market and the New Economy', Economy and Society 30(4): 467-503.

Finnegan, R. (1989) The Hidden Musicians: Music-making in an English Town. Cambridge: Cambridge University Press.

Frith, S. (1987) 'The Making of the British Record Industry, 1920-64', in J. Curran, A. Smith and P. Wingate (eds) Impacts and Influences. London: Methuen.

Garofalo, R. (1999) 'From Music Publishing to MP3: Music and Industry in the 20th Century', American Music 17(3): 318-53.

Gelder, K. and S. Thornton (eds) (1996) The Subcultures Reader. London: Routledge.

Gladwell, M. (2000) The Tipping Point: How Little Things Can Make a Big Difference. London: Abacus.

Hennion, A. (1989) 'An Intermediary between Production and Consumption: The Producer of Popular Music', Science, Technology and Human Values 14(4): 400-24.

Hesmondhalgh, D. (1998) 'The British Dance Music Industry: A Case Study of Independent Cultural Production', British Journal of Sociology 49(2): 234-51.

IFPI (2002) 'Piracy Report', available on-line: http://www.ifpi.org/site-content/ antipiracy/piracy2002.html

Johnson, J. (2002) Who Needs Classical Music? Cultural Choice and Musical Values. Oxford: Oxford University Press.

Jones, S. (2002) 'Music that Moves: Popular Music, Distribution and Network Technologies', Cultural Studies 16(2): 213-32.

Lanza, Joseph (1995) Elevator Music: A Surreal History of Muzak, Easy-listening, and Other Moodsong. New York: Quartet.

Lewis, M. (2001) The Future Just Happened. London: Hodder and Stoughton.

Leyshon, A. (2001) 'Time-space (and Digital) Compression: Software Formats, Musical Networks, and the Reorganisation of the Music Industry', Environment and Planning A 32: 49-77.

Leyshon, A. (2003) 'Scary Monsters? Software Formats, Peer-to-peer Networks, and the Spectre of the Gift', Environment and Planning D: Society and Space 21(5): 533-58.

Leyshon, A. and N. Thrift (1997) Money/Space: Geographies of Monetary Transformation. London: Routledge.

Leyshon, A., S. French and N. Thrift, (2005) 'Accounting for E-commerce: Abstractions, Virtualism and the Cultural Circuit of Capitalism', Economy \& Society (in press).

Malbon, B. (1999) Clubbing: Dancing, Ecstasy and Vitality. London: Routledge.

McCourt, T. and P. Burkart (2003) 'When Creators, Corporations and Consumers Collide: Napster and the Development of On-line Music Distribution', Media Culture \& Society 25(3): 333-50.

Negus, K. (1992) Producing Pop: Culture and Conflict in the Popular Music Industry. London: Edward Arnold.

Negus, K. (1995) 'Where the Mystical Meets the Market: Creativity and Commerce in the Production of Popular Music', Sociological Review 43(2): 316-41.

Rifkin, J. (2000) The Age of Access: How the Shift from Ownership to Access is Transforming Capitalism. London: Penguin.

Sadler, D. (1997) 'The Global Music Business as an Information Industry: Reinterpreting Economies of Culture', Environment and Planning A 29: 1919-36. 
Sandall, R. (2003) 'The Day the Music Industry Died', Sunday Times Magazine 16 February: 24-30

Sanghera, S. (2002)'Rock 'n' Roll Suicide: How Napster, TV-created Pop and a Dearth of Talent are Killing the Record Industry', Financial Times 15 November: 19.

Sanjek, R. (1988) American Popular Music and its Business, Volume II: 1909-1984. New York: Oxford University Press.

Schoenberger, E. (1997) The Cultural Crisis of the Firm. Oxford: Blackwell.

Scott, A.J. (1999) 'The US Recorded Music Industry: On the Relations between Organization, Location, and Creativity in the Cultural Economy', Environment and Planning A 31: 1965-84.

Scott, A.J. (2000) The Cultural Economy of Cities: Essays on the Geography of Image-producing Industries. London: Sage.

Tehranian, J. (2003) Optimizing Piracy: The Uses and Limits of Intellectual Property Enforcement in the Cyberage (mimeograph: available from author at S.J. Quinney College of Law, University of Utah).

Theberge, P. (1997) Any Sound You Can Imagine: Making Music/Consuming Technology. Middletown, CT: Wesleyan University Press.

Thornton, S. (1995) Club Cultures: Music, Media and Subcultural Capital. Cambridge: Polity.

Vaidhyanathan, S. (2001) Copyrights and Copywrongs: The Rise of Intellectual Property and How it Threatens Creativity. New York: New York University Press.

Zook, M. (2003) 'Underground Globalization: Mapping the Space of Flows of the Internet Adult Industry', Environment and Planning A 35(7): 1261-86.

Andrew Leyshon is Professor of Economic Geography at the University of Nottingham. Previously he has worked at the Universities of Wales, Hull and Bristol. In addition to investigating the origins and impacts of ecommerce, he is also currently researching the formation of ecologies of retail financial services. He is the author of Money/Space: Geographies of Monetary Transformation (with Nigel Thrift, Routledge, 1997) and coeditor of The Place of Music (with David Matless and George Revill, Guilford, 1998) and Alternative Economic Spaces (with Roger Lee and Colin Williams, Sage, 2003).

Address: School of Geography, University of Nottingham, Nottingham, NG2 7GW, UK. [email: Andrew.Leyshon@ nottingham.ac.uk]

Peter Webb studied politics and sociology at the Universities of the West of England and Bristol. He is currently a Lecturer in Sociology at the University of Birmingham, Prior to this he was Research Fellow at the University of Bristol. He has published work on popular music and social theory. He is also a musician who releases material under the name of 'Statik Sound System'.

Address: Department of Sociology, University of Birmingham, 32 Pritchatts Road, Edgbaston, Birmingham B15 2TT, UK. [email: p.m.webb@bham. ac.uk] 
Shaun French is currently Lecturer in Economic Geography at the University of Nottingham, having previously studied at the University of Bristol. He has published work on the geographies of business knowledge and praxis.

Address: School of Geography, University of Nottingham, Nottingham, NG2 7GW, UK. [email: Shaun.French@ nottingham.ac.uk]

Nigel Thrift has taught or carried out research at the Universities of Bristol, Cambridge, Leeds, Wales, Uppsala, UCLA, the Australian National University and the National University of Singapore. He is currently Head of the Division of Life Sciences at the University of Oxford. Most recently, he is the author of Cities (with Ash Amin, Polity, 2002), The Cultural Geography Handbook (co-edited with Kay Anderson, Mona Domosh and Steve Pile, Sage, 2003) and Patterned Ground (co-edited with Stephan Harrison and Steve Pile, Reaktion, 2003). He is currently working on informational ecologies and body technologies.

Address: Division of Life Sciences, University of Oxford, 9 Parks Road, Oxford OX1 3UB, UK. [email: nigel.thrift@admin.ox.ac.uk]

Louise Crewe is Professor of Human Geography at the University of Nottingham. Her interests lie in the areas of fashion, retailing, shopping and consumption with particular focus on commodity biographies, value and second-hand exchange. She is the co-author of Second-hand Cultures (with Nicky Gregson, Berg, 2003).

Address: School of Geography, University of Nottingham, Nottingham, NG2 7GW, UK. [email: Louise.Crewe@ nottingham.ac.uk] 